\title{
Ortaokul Denetim Rehberinin Alanyazın ve Yasal Belgeler Temelinde incelenmesi
}

\author{
Prof. Dr. Erdal Toprakçı \\ Ege Üniversitesi-Türkiye \\ erdal.toprakci@ege.edu.tr
}

\author{
Ahmet Bulut(Y.L.Öğr.) \\ Milli Eğitim Bakanlığı-Türkiye \\ ahmetbulut.1907.ab@gmail.com
}

Özet:

Bu araştırmanın amacı alanyazın ve yasal belgeler temelinde, daha nitelikli ve daha uygulanabilir rehberler üretme adına, Ortaokul Denetim Rehberini analize tabii tutarak araştırmacı ve uygulamacılara öneriler sunmaktır. Araştırmanın problemine uygun olarak nitel araştırma temelinde belg, doküman inceleme yöntemi kullanılmıştır. Veriler içerik analizi yöntemiyle çözümlenmiştir. Araştırmanın veri kaynaklarını Milli Eğitim Bakanlığı Teftiş Kurulu Başkanlığı'nın resmi web sayfasında yayınlanan "Ortaokul Denetim Rehberi", Milli Eğitim Bakanlığı'nın rehber ve denetimle ilgili yasal belgeleri (kanun, kanun hükmünde kararname, tüzük, yönetmelik, yönerge ve genelge) ve eğitim denetimi ile ilgili alan yazın oluşturmaktadır. Araştırmanın bulguları, Ortaokul denetim rehberinin yasal belgelerle ve alan yazınla ilişki temelinde incelenmiştir. Araştırmada, sonuç olarak, Ortaokul denetim rehberi yasal belgelerle ilişkilendirldiğinde en çok "Yasal dayanağa göre eksik ifade edildiği bulgusuna ulaşılmıştır. Ortaokul denetim rehberi alayazın bağlamlı incelendiğinde ise alanyazın ile tutarlı olduğu; tutarsızlığının ise en çok "alanyazın desteği olmadığı" sonucuna ulaşılmıştır. Ortaokulların denetiminde rehberden kaynaklanabilecek sorunların önüne geçebilmek adına rehberin yasal belgeler ve alanyazınla daha fazla ilişkilendirilmesi gerektiği önerilebilir.

Keywords: Eğitim, Eğitim denetimi, Ortaokulun denetimi, Denetim rehberi

.

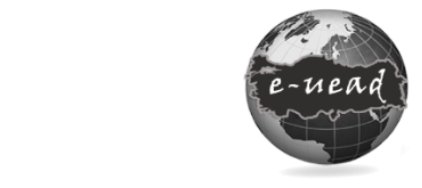

E-Uluslararası Eğitim

Araşturmaları Dergisi,

Cilt: 12, Sayt: 1, 2021, ss. 16-35

DOI: 10.19160/ijer.830418

\section{Önerilen Atıf}

Toprakçı, E. \&. Bulut, A. (2021). Ortaokul Denetim Rehberinin Alanyazın ve Yasal Belgeler Temelinde İncelenmesi, EUluslararası Eğitim Araştırmaları Dergisi, Cilt: 12, Sayı: 1, 2021, ss. 16-35, DOI: 10.19160/ijer.830418 


\section{Giriş}

Toplumsal yapıda din, aile, siyaset, hukuk, ekonomi, eğlence, sağlık, ulaşım-iletişim, eğitim ve güvenlik gibi pek çok kurum ve kuruluş vardır (Toprakçı, 2008). Eğitim de bu kurum ve kuruluşlardan biridir. Eğitim kurumlarının yaşamsallığı paralelinde yönetim ve denetimlerini de önemli bir hale getirmektedir. Yönetimde planlama ve uygulama sonuçlarını değerlendirme örgütler için önemlidir. Belli bir amacı gerçekleştirmek adına bir araya gelmiş insanlardan oluşan örgütler için değerlendirme bir gerekliliktir, yönetimsel bir intiyaçtır. Yönetim aşamalarının sonuncusu ve vazgeçilmezi değerlendirme sürecidir(Demirtaş ve Akarsu, 2016). Üretilen ve gerçekleştirilenlerin kontrolü, eksiklik ve yanlışıkların düzeltilmesi, amacın gerçekleştirilmesi açısından bir zorunluluktur. Eğitim sisteminde ulaşılması istenen hedefler doğrultusunda mevcut kaynakların nitelikli ve amaca uygun olması, her zaman beklenen nitelikli ürünlerin ortaya çıkması için yeterli olmayabilir. Denetim Süreci okullarda öğretim hizmetlerinin gözlenmesi ve sonrasında geliştirilmesi ve iyileştirilmesi açısından denetim gerekli ve önemli bir süreçtir (Beytekin ve Tas, 2017). Denetim öğretmenlerin gelişimlerini teşvik etmek adına uygulama, sorumluluk ve haklarını geliştirmelerine katkıda bulunma (Nolan ve Hoover, 2008) süreci olarak da görülmektedir. Aydın (2005)'a göre denetim, örgütün amaçlarını gerçekleştirme derecesini saptamak, daha iyi sonuç alabilmek için gerekli önlemleri almak ve süreci geliştirmektir. Eğitimöğretim işlevlerinin değerlendirilmesi, eğitim sisteminin etkililiği ve verimliliği açısından yerine getirilmesi gereken önemli bir süreçtir. Bu nedenle eğitim denetimi eğitim her safhasında mutlaka gerçekleştirilmelidir. Çünkü eğitim örgütlerinin amaçlarına ulaşmasında denetimin yeri oldukça büyüktür. Bu bağlamda Toprakçı (2008)' ya göre "Eğitim denetimi, yapılmış ya da yapılmakta olan eğitim faaliyetlerinin amaca uygun olarak gerçekleşip gerçekleşmediğini saptama sürecini inceleyen, açıklayan ve bu süreci öndeyileyen bilim dalıdır". Yine alanyazında eğitim denetimi, eğitimde gerçekleştirilen ve/veya gerçekleştirilmekte olan eylemlerin; mevcut yasal işleyişe, belirlenen amaca, hazırlanan plana, eldeki madde ve insan kaynaklarına uygun olup olmadığını kontrol etme sürecidir(Toprakçı, Çakırer, Bilbay, Bağcivan \& Bayraktutan, 2010) şeklinde ifade edilmektedir.

Türkiye'nin eğitim tarihi incelendiğinde eğitim ve öğretim hizmetlerinin devlet eliyle yürütülmesi düşüncesi ilk kez II. Mahmut döneminde gündeme gelmiştir. Bu döneme kadar vakıflar tarafından yürütülmüş olan eğitim ve öğretim hizmetleri,1857'den başlayarak Maarif-i Umumiye Nezareti uhdesine verilmiş ve bugünkü durumun alt yapısı kabul edilebilecek bir takım değişiklikler yapılmıştır(MEB, 2015). 1911 tarihli Maarif-i Umumiye ve Teşkilatı Nizamnamesi (Eğitim Teşkilat Tüzüğü) ile bütünsel bir yapı oluşturulmuştur. Son bir kaç yılda da bu yapıya başka birimler de (Telif ve Tercüme Dairesi, Özel Kalem ve Evrak Dairesi) ilave edilmştir. Günümüze gelindiğinde Millî Eğitim Bakanlığının teşkilat yapısı çeşitli yasal düzenlemelerle (Tehvid-i Tedrisat, Harf İnkılabı, Illköğretim Kanunu, 652 Sayılı Khk vb.) değişikliklere uğramıştır (MEB, 2015). Türk eğitim sisteminin önemli bir parçası olarak maarif müfettişliğinin (denetçiliği) tarihsel süreci incelendiğinde ise Cumhuriyet öncesi varlığı temelinde yaklaşık 170 yıllık bir geçmişe sahip olduğu görülmektedir. Osmanlı Döneminde ilk olarak 1846 yılında Mekatib-i Sıbyaniye Muinliği (Illköğretim Müfettişliği) ve Mekatib-i Rüşdiye Muinliği (Orta Öğretim Müfettişliği) adlarında iki birim kurularak, okullardaki rehberlik ve teftiş görevi Muinler (Müfettişler) aracılığı ile yapılmıştır (Aydın, 2000). Tarihi süreç içerisinde müfettişlik kurumu güçlenerek Türk Eğitim sistemine büyük katkılar sağlamıştır. Eğitim sistemimizdeki gelişmeler ve yenilikler çerçevesinde müfettişlik sisteminde de zaman zaman yeni düzenlemelere gidilmiştir. Bu tarihi süreç içerisinde en köklü değişim son beş yılda yaşanmış, bu süre zarfında üç ayrı yasal düzenleme yapılmıştır. Milli Eğitim Bakanlığında 14 Eylül 2011 tarihli 652 Sayılı Kanun Hükmünde Kararnameyle Milli Eğitim Bakanlığı teşkilatı yeniden yapılandııılmıştır. Bu yapılandırmada Bakanlık Müfettişlerine "Milli Eğitim Denetçisi", II emrinde çalışan Eğitim Müfettişlerine ise "il Eğitim Denetmeni" unvanı verilmiştir. Bu Kanun Hükmünde Kararname ile II Eğitim Denetmenlerinin görev alanları iyice genişletilmiş, daha önce görev alanında olmayan İ ve İlçe 
Milli Eğitim müdürlüklerinin denetimi ile ortaöğretim kurumlarının denetimleri de illerde görev yapacak II Eğitim Denetmenlerine verilmiştir. Son olarak, Milli Eğitim Bakanlığı; 14.03 .2014 tarih ve 28941 Sayılı R.G.'de yayımlanan "6528 Sayılı Millî Eğitim Temel Kanunu ile Bazı Kanun ve Kanun Hükmünde Kararnamelerde Değişiklik Yapılmasına Dair Kanun" ile gerekli düzenlemeyi yaparak, Milli Eğitim Denetçileri ile II Eğitim Denetmenlerini tek çatı altında toplamış ve birleşen bu müfettişlere "Maarif Müfettişi" adını vermiştir. Bu yasa ile müfettişlerin görev tanımları ve görev kapsamı tekrar belirlenmiş̧tir. Söz konusu; 6528 Sayılı Yasa ile yapılan değişiklik sonucunda; 652 sayılı Milli Eğitim Bakanlığının Teşkilat ve Görevleri Hakkında Kanun Hükmünde Kararnamesinin 17. maddesinde, MEB Rehberlik ve Denetim Başkanlığının görevleri sayılırken (d) fıkrasında "Her derece ve türdeki örgün ve yaygın eğitim kurumları ile il ve ilçe millî eğitim müdürlüklerinin rehberlik, işbaşında yetiştirme, denetim, değerlendirme, inceleme, araştırma ve soruşturma hizmetlerini Maarif Müfettişleri aracılığıyla yürütmek" hükmü yer almış ve bu hüküm maarif müfettişlerinin görev alanlarını belirlemiştir. Bu yasal düzenlemeye bağlı olarak çıkartılan 24.05.2014 tarih ve 29009 Sayılı Resmi Gazetede yayınlanan 'Millî Eğitim Bakanlığı Rehberlik ve Denetim Başkanlığı İle Maarif Müfettişleri Başkanlıkları Yönetmeliği' maarif müfettişlerinin teşkilatlanma yapısını, görev, yetki ve sorumluluklarını, atanmalarını, çalışma usul ve esaslarını belirlemiştir. Gelişmeler, öğretmenler için mesleki yeterlik, kişisel yetenek ve yeterlik, ilgi zenginliği ve bilgi birikimi bakımından sürekli ve nitelikli bir rehberlik hizmetini zorunlu bir intiyaç haline getirmektedir. Bu bağlamda, yasal ve yönetsel metinlerle uygulama boyutunda oldugu gibi kuramsal çerçevede de ögretmene rehberlik etmesi öngörülen baslıca değişkenin, denetmen olduğu anlaşılmaktadır(Sabancı ve Şahin, 2007). Denetmenin de denetim esnasında ilk başvuracağı kaynağı ve kılavuzunun denetim rehberi olacağı düşünülmektedir.

Türkiye'de Cumhuriyetin ilanıyla toplumsal dönüşümün önemli bir ayağı olarak görülen eğitime büyük önem verilmiş ve eğitimin denetimi de uzun yıllar eğitim uygulamalarını kontrol altında tutma anlayışıyla yürütülmüştür. Eğitim denetiminin kapsamını öğrenciler, öğrencilerin güvenliği ve davranışları, akademik başarı, öğretmen performansı, okuldaki öğretimin niteliği, okul yönetimi vb. gibi eğitim ile doğrudan ve dolaylı ilişkili birçok faaliyet oluşturur. Bu bağlamda Milli Eğitim Bakanlığı'nın (MEB) sorumlu olduğu denetim uygulamalarından biri de okul/kurum denetimidir. Okul/Kurum denetimi, bir eğitim kurumunu amaçlarını gerçekleştirmede insan ve madde kaynaklarının sağlanma ve faydalanma durumunun gözlenmesi, kontrol edilmesi ve belli ölçütlere göre değerlendirilmesidir (Demirtaş ve Güneş, 2002). Başka bir ifadeyle okul ve kurumların eğitim-öğretim etkinlikleri ile yönetim çalışmalarının, yürürlükteki yasal metinler çerçevesinde uygunluk ve verimlilik açsından durumunun saptanması, personelin iş başında yetiştirilmesi, eğitim hedef ve amaçlarına ulaşma düzeyinin tespit edilmesi amacıyla yapılan denetim etkinliklerinin bütündür(MEB, 2019). Son olarak 20.08.2017 tarih ve 30160 sayılı Resmi Gazetede yayınlanarak yürürlüğe giren MEB Teftiş Kurulu Yönetmeliğine göre okullarda kurum denetimi Maarif Müfettişlerince gerçekleştirilmektedir (MEB, 2017a). Sabancı ve Şahin(2007)'e göre öğretmenler ise müfettiş ya da deneticilerden hem kişisel ve de hem meslekî gelişimlerine yönelik bir rehberlik hizmeti beklemektedirler. Araştırmacılar kurum denetimi ve rehberlik hizmeti gerçekleştirilirken beş boyut üzerinde durmaktadır. Bu beş boyutun: (1) meslekî değerler ve kişisel gelişim, (2) öğretme ve öğrenme sürecine ilişkin yeterlikler, (3) okul-aile-çevre ilişkileri, (4) program geliştirme ve içerik bilgisi, (5) öğrenci rehberlik hizmetleri olduğunu belirtmişlerdir. Bu bağlamda Maarif Müfettişleri görevlerini yerine getirirken kılavuzluk etmesi ve yol göstermesi için MEB Teftiş Kurulu Başkanlığı tarafından "Rehberlik ve Denetim Rehberleri" hazırlanmıştır. Milli Eğitim Bakanlığı Teftiş Kurulu Başkanlığı görev, yetki, sorumluluk ve çalışma esaslarının yer aldığı yönergede Rehberlik ve Denetim Daire Başkanlığının görevleri kapsamında "Madde 25: g) Bakanlık merkez, taşra ve yurtdışı teşkilatı ile okul, kurum ve personelin rehberlik ve denetimine ilişkin esasların ve rehberlerin hazırlanması, uygulanması ve geliştirilmesine ilişkin iş ve işlemleri yürütmek." ifadesine göre mevcut denetim rehberinin güncel tutulması da görevler kapsamında belirtilmiştir. Bu rehberlerden biri de Ortaokul Rehberlik ve Denetim Rehberidir. 
Alanyazın incelendiğinde Türkiye'de ilköğretimde eğitim ve okul kurumu denetimi ile ilgili yapılan araştırmalar denetim alt sisteminin görevini çağdaş anlamda yerine getiremediğini, ihtiyaçlara cevap veremediğini ve bu alanda pek çok eksiklerin olduğunu ve sorunların yaşandığını ortaya koymuştur (Gökçe, 1994; Bozkurt, 1995; Özbek, 1998; Sağlam, 2002; Sarpkaya, 2004; Yıldııım, 2007; Göktaş, 2008; İnal, 2008; 2009; Bayraktutan, 2011; Eroğul, 2012; Uçar, 2012; Toprakçı ve Kadı, 2014; Fırıncıoğulları Bige, 2014; Toprakçı ve Akçay, 2016; Toprakçı ve Bakır, 2019). Bu kapsamda alanyazında ortaokulların denetimi ile ilgili çalışmalara yer verildiği, yapılan araştırmaların, genellikle eğitim sisteminin paydaşlarından bir ya da iki kesiminin görüşleri temelinde yürütüldügü ancak denetçilerin denetim sürecince kullandıkları denetim rehberlerinin incelenmesi ile ilgili herhangi bir çalışma yapılmadığı görülmüştür.

Rehber hem denetlenen kuruma hem de denetleyene yol gösteren bir belgedir. Bu belgenin uygulamaya yaynsıyabilmesi için de olanak ölçüsünde en az eksik ve hata barındıran nitelikte olması gerekir. Bunun için de bilimsel bir analize tabi tutmak üzere özellikle eğitim denetimi alanyazını ve yasal belgeler temelli bir inceleme yararlı olabilir. Bir denetim rehberi yasalara dayanmalıdır. Eğer denetim rehberi yasalara dayanmazsa sorunlar çıkar. Öte yandan denetim rehberinin bilimsel bilgiye dayanması gerektiği de ortadadır. Bilimsel bilginin, yasaları etkileme ve belirleme işlevi bilimi kültür haline getirmiş toplumlarda yaygın olmakla birlikte ülkemizde bu kültürün var olduğunu söylemek pek de doğru gözükmemektedir. Bu temelde söz konusu okulların denetim rehberinde de bu özellik aranabilmelidir. Denetim rehberi eğer bu özellik ile donanmış olursa nitelikli bir denetsel faaliyetin gerçekleşebileceği de ortadadır. Bu kapsamda araştırmanın amacı alanyazın ve yasal belgeler temelinde, daha nitelikli ve daha uygulanabilir rehberler üretme adına, ortaokul denetim rehberini analize tabii tutarak elde edilen bulgular ve sonuçlar ışığında araştırmacı ve uygulamacılara öneriler sunmaktır.

\section{YÖNTEM}

\section{Araştırmanın modeli:}

Araştırmanın problemine uygun olarak nitel araştırma temelinde doküman inceleme yöntemi kullanılmıştır. Nitel araştırmanın seçilmesinin nedeni ortaokul denetimi rehberini bütüncül olarak irdelemektir. Çünkü nitel araştırmalar, algıları ve olayları doğal ortamda gerçekçi ve bütüncül bir biçimde ortaya koyar ve toplanan verilerden yola çıkarak daha önceden fark edilmeyen sonuçları birbiriyle ilişkili bir şekilde açıklar (Yıldırım ve Şimşek, 2005: 39). Doküman incelemesi ise araştıııması hedeflenen kavram veya olguların, konu hakkında bilgi içeren yazılı belgelerden elde edilen verilerle incelenmesini ifade etmektedir (Yıldııım \& Şimşek, 2005). Bu yöntemin uygulanması beş aşamadan oluşmaktadır. Bunlar; dokümanlara ulaşma, dokümanların orijinalliğini kontrol etme, dokümanları anlama, veriyi analiz etme ve kullanma (Yıldırım ve Şimşek, 2016). Bu bağlamda Ortaokul Rehberlik ve Denetim Rehberinin ilgili MEB denetim mevzuatı çerçevesinde uygulama birliğini ve standartlaşmayı sağlamak amacıyla, Rehberlik ve Denetim Rehberleridoküman incelenmesine uygun kaynaklar olarak görülmüş ve doküman incelemesinin aşamalarına göre analiz edilmiştir.

\section{Çalışma dokümanı:}

MEB Teftiş Kurulu Başkanlığı, 2016 yılında çeşitli kurumların teftişine yönelik olarak hazırlanan 16 adet rehberlik ve denetim rehberi yayımlamıştır. Bu rehberler maarif müfettişlerinin teftiş sürecinde uygulayacakları esasları içermektedir. Çalışma dokümanı yayımlanan rehberler arasında yer alan "Ortaokul Denetim Rehberi'dir". Söz konusu belgeye, MEB Teftiş Kurulu Başkanlığı'nın internet sitesinin "Yayınlarımız" sayfasından 24.04.2020 tarihinde ulaşılmıştır. Diğer yandan yasal ve alanyazın belgelerine ulaşma konusunda ise çevrim içi ortam (Google Akademik, Mevzuat - resmi siteleri, Google ve Yandex'de anahtar kavram bazlı tarama) ile araştırmacıların gerçek ve sanal kütüphanelerinde bulunan kaynaklardan yararlanılmıştır. Buna göre ulaşılan 
belgeler (rehber hariç olmak üzere) sınırlılı̆ında bir incelemenin gerçekleştirildiğini belirtmek gerekir.

\section{Verilerin Toplanması ve Analizi:}

Doküman incelemesi tekniğinin uygulanması beş aşamadan oluşmaktadır: Dokümanlara ulaşma, dokümanların orijinalliğini kontrol etme, dokümanları anlama, veriyi analiz etme ve kullanma (Forster, 1995: Akt. Yıldırım ve Şimşek, 2013). Dokümanlara ulaşma aşamasında "Ortaokul Rehberlik ve Denetim Rehberine" Milli Eğitim Bakanlığı Teftiş Kurulu Başkanlığı'nın resmi internet sitesinden; ardından rehberde bahsi geçen ilgili kanun, yönetmelik, yönerge, genelge ve diğer belgelere yine bakanlığın kendi sitesinden ulaşılmıştır ve orijinalliği (gerek uzmanlar gerekse diğer çevrimiçi olanaklar bağlamında) teyit edilmiştir. Dokümanları anlama aşamasında öncelikle ilgili rehber ardından rehberde bahsi geçen mevzuat detaylı olarak incelenmiştir.

Veriler, içerik analizine tabi tutulmuştur. İçerik analizinde temelde yapılan işlem, birbirine benzeyen verileri belirli kavramlar ve temalar çerçevesinde bir araya getirmek ve bunları okuyucunun anlayabileceği bir biçimde düzenleyerek yorumlamaktır (Yıldırım ve Şimşek, 2013: 259). iç̧erik analizi; verilerin kodlanması, temaların bulunması, kodların ve temaların düzenlenmesi, bulguların tanımlanması ve yorumlanması aşamalarından oluşmaktadır (Yıldırım ve Şimşek, 2013). Bundan dolayı verilerin analizi aşamasında öncelikle söz konusu rehber ve gönderme yaptığı yasal belgeler ön inceleyerek; alanyazın ile ilişkisinin analizi işlemi için ise, araştırmacılar rehberi çevrim içi ortam ile gerçek ve sanal kütüphaneleri yardımcı araçları ile "alanyazınsal zihin çerçeveleri" sınırlığında aşkınlık seviyesine gelinceye kadar okuyarak kod, kategori ve temalara ulaşmışlardır. Alanyazın ile ilişkisi ise çalışmayı yapanların bulunan kaynaklar ile "alanyazınsal zihin çerçeveleri" sınırlıığında gerçekleştirilmiştir. Bu süreçte çelişkiye düşülen durumlarda kaynaklara, meslektaş teyidine, uzman görüşüne başvurulmuştur. Buna göre tersinden ifade etmek gerekirse; bir denetim rehberinin yasa ve alanyazın ile olan ilişkisi temalar olarak biçimlenirken, yasal belgeler ve alanyazın ile ilişkisinde tutarlılık ve tutarsızlık şeklinde kategoriler, ayrı ayrı olmak üzere onların altında da "Yasal dayanağa uygunluk", "Yasal dayanağa göre güncel olmama", "Yasal dayanak belirsizliği", "ilgili yasal dayanaklara eksik gönderme", "Yasal boşluk", "Yasal dayanağa internet ortamında ulaşamama", "Yasal dayanağa göre eksik ifade edilme", "Yasal dayanağın hatalı ifade edilmesi", "Yasal dayanağa göre fazla ifade edilme", "Karşılıksız", "Uygunluk", "içerik eksikliği", "Atıfsızlık", "Kavram tutarsızlığı" ve "Aykırlık" şeklinde kodlar ortaya çıkmıştır. Verilerin bulguya dönüşmesinde anlaşılmayı kuvvetlendirmek verilerin yüzde dağılımı ya da sayısallaştırma yoluna da gidilmiştir. Son olarak veriyi kullanma aşamasında belirlenen temalara göre uygun olan alıntılarla analiz desteklenmiş ve yorumlanmıştır. Yapılan içerik analizine birkaç örnek Tablo 1'de verilmiştir.

Tablo 1'de görüldüğü gibi, veri analiz sürecinin daha iyi anlaşılması için denetim rehberinde yer alan "Denetim Rehberinin Yasal Belgelerle Tutarlıı̆ı", "Denetim Rehberinin Yasal Belgelerle Tutarsızlığı", "Denetim Rehberinin Alanyazınla Tutarlıı̆ı" ve "Denetim Rehberinin Alanyazınla Tutarsızlığı" kategorilerine uygun olan ifadelerden birer örnek verilmiştir.

\section{Geçerlik ve Güvenirlik}

Çalışmanın geçerliğinin ve güvenilirliğini sağlamak için çeşitli teknikler kullanılmıştır. Geçerlik ve güvenirliğini artırmak adına, dışarıdan bir uzmanın ulaşılan yargıların, yorumların ve önerilerin ilk verilerle uygunluk derecesine bakarak bir değerlendirme yapması olarak nitelendirilen "teyit incelemesi" stratejisinden (Yıldırım ve Şimşek, 2005: 272) yararlanılmıştır. Ayrıca alan yazında, uzman görüşü alma, doğrudan alıntılara yer verme, çeşitleme yoluna gitme, birden fazla araştırmacıyı dahil etme ile araştırmanın güvenirliğinin artırılabileceği vurgulanmaktadır (Glesne ve Peshkin, 1992;Shenton, 2004; Yıldırım ve Şimşek, 2005). 
Tablo1: Ortaokul Denetim Rehberi Içerik Analizi Örnekleri

\begin{tabular}{|c|c|c|c|}
\hline Tem & Kategori & Kodlar & Temayla ilişkili ifadeler ve Gönderme yapılan yasal belge/ ilgili madde \\
\hline \multirow{4}{*}{ 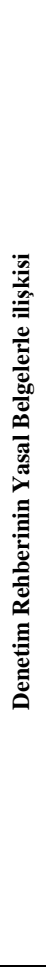 } & \multirow{2}{*}{ 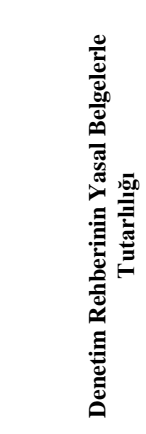 } & 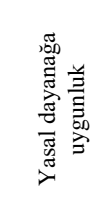 & $\begin{array}{l}\text { Rehberde: } \\
3.1 .3 \text { Rehberlik Denetim Esasları Açısından, Rehberlik ve Denetim Uygulama Süresi, } \\
\text { "Rehberlik ve denetim uygulamalarında, son denetim tarihinden itibaren yürütülen iş ve işlemler } \\
\text { esas alınır. Ancak son denetim tarihi üç yıldan önce ise son üç yıl dikkate alınır." } \\
\text { Yasal belgedeki karşılığı: } \\
\text { Millî Eğitim Bakanlığı Teftiş Kurulu Yönetmeliği MADDE 49- (7) Bakanlık teşkilatı birimleri } \\
\text { ile okul ve kurumların denetiminin üç yılda bir periyodik olarak yapılması esastır. }\end{array}$ \\
\hline & & \multicolumn{2}{|c|}{$\begin{array}{l}\text { Denetim rehberinde "3.1.3 Rehberlik Denetim Esasları Açısından, } 3.1 \text { Rehberlik ve Denetim Uygulama Süresi" } \\
\text { başlığı altında yer alan söz konusu ifade yasal belgeler bağlamında incelendiğinde rehberlik ve denetim } \\
\text { uygulama süresinin hem rehberde hem de yasal belgede üç yıl olduğu görülmüş, rehberdeki ifadenin yasal } \\
\text { belgeyle tutarlı olduğu sonucuna ulaş1lmıştır. Bu bağlamda ilgili ifade tutarlılı kategorisi başlığı altında } \\
\text { "Yasal dayanağa uygunluk" kodu içerisinde yer almıştır. }\end{array}$} \\
\hline & \multirow{2}{*}{ 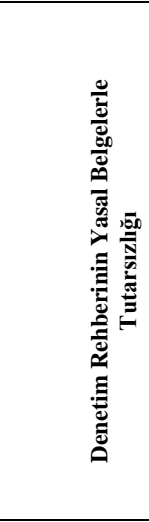 } & 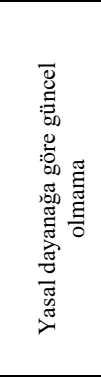 & $\begin{array}{l}\text { Rehberde: } \\
\text { Rehberde Öğretim Etkinlikleri, Ölçme Değerlendirme: İlkokul } 4 \text { üncü sınıf ile ortaokul ve } \\
\text { imam hatip ortaokullarında ögrencilere; Haftalık ders saati üç ve üçten az olan derslerde iki, } \\
\text { üçten fazla olan derslerde ise üç sınav yapılması, sınavların zamanının, en az bir hafta } \\
\text { önceden öğrencilere duyurulmass, bir sınıfta/şubede bir günde yapılacak sınav sayısının } 8 \text { inci } \\
\text { sınıfta üçü, diğer sınıflarda ikiyi geçmemesi, sınavların süresinin bir ders saatini aşmaması } \\
\text { (Millî Eğitim Bakanlığı Okul Öncesi Eğitim ve Illköğretim Kurumları Yönetmeliği Md. 22) } \\
\text { Yasal belgedeki karşılığı: } \\
\text { İlköğretim Kurumlar Yönetmeliği madde } 22-(1) \text { İlkokul } 4 \text { üncü sınıf ile ortaokul ve imam- } \\
\text { hatip ortaokullarında öğrencilere; a) (Değişik: RG-31/1/2018-30318) 4, 5, } 6 \text {, } 7 \text { ve } 8 \text { inci } \\
\text { sınıflarda her dersten bir dönemde iki sınav yapılır. Sınavların zamanı, en az bir hafta önceden } \\
\text { öğrencilere duyurulur. Bir sınıfta/şubede bir günde yapılacak sınav sayısı ikiyi, her bir sınav } \\
\text { süresi ise bir ders saatini geçemez. }\end{array}$ \\
\hline & & \multicolumn{2}{|c|}{$\begin{array}{l}\text { Denetim rehberinde "Rehberde Öğretim Etkinlikleri, 2.2.3. Ölçme Değerlendirme" başlığı altında yer alan söz } \\
\text { konusu ifade yasal belgeler bağlamında incelendiğinde haftalık ders saatlerine göre dönemlik sınav sayılarında } \\
\text { tutarsızlık olduğu görülmüş ve Okulöncesi ve İlköğretim Kurumlar Yönetmeliği 22. maddesine göre güncel } \\
\text { olmadığ1 sonucuna ulaşılmıştır. Bu bağlamda ilgili ifade tutarsızlık kategorisi başlığı altında "Yasal dayanağa } \\
\text { göre güncel olmama" kodu içerisinde yer almıştır. }\end{array}$} \\
\hline \multirow{4}{*}{ 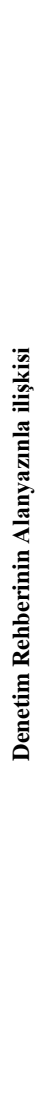 } & \multirow{2}{*}{ 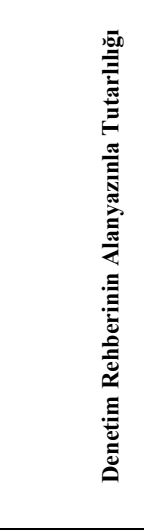 } & 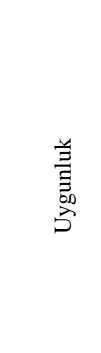 & $\begin{array}{l}\text { Rehberde: } \\
\text { 3.1.4 Rehberlik Denetim Raporlama Standardı ve Değerlendirme Açısından; İlkokul, Ortaokul } \\
\text { ve İmam Hatip Ortaokullarında; Okul-Çevre İlişkileri; } \\
\text { 1.Eğitim-öğretim etkinliklerinde okul, aile ve çevre iliş̧kilerinin incelenmesi } \\
\text { 2. Sosyal ve kültürel etkinliklerin aile ve çevre ile paylaşma durumunun incelenmesi (MEB } \\
\text { İlköğretim ve Orta Öğretim Kurumları Sosyal Etkinlikler Yönetmeliği). } \\
\text { Alanyazında: } \\
\text { Okul-Aile-Çevre İlişkileri: Okul-çevre ilişkileri dört boyutta ele alınabilir; } \\
\text { 1. Çevre kalkınmasına okulun katkıda bulunması, } \\
\text { 2. Okul-aile iş birliği ve aile katılımının sağlanması, } \\
\text { 3. Baskı grupları, gönüllü kişi ya da gruplarla ilişkiler, } \\
\text { 4. Çevrenin eğitime desteğinin sağlanması ve halkla ilişkiler (Pehlivan, 2000, 108). }\end{array}$ \\
\hline & & \multicolumn{2}{|c|}{$\begin{array}{l}\text { Denetim rehberinde "3.1.4 Rehberlik Denetim Raporlama Standardı ve Değerlendirme Açısından; İlkokul, } \\
\text { Ortaokul ve İmam Hatip Ortaokullarında; 2.3.3. Okul-Çevre İlişkileri" başlığı altında yer alan söz konusu ifade } \\
\text { incelendiğinde hem rehberde hem de alanyazında okul-aile-çevre ilişkilerinden bahsedildiği görülmüştür. İlgili } \\
\text { ifade denetim rehberinin alanyazınla tutarlılığı kategorisi altında "Alanyazına göre uygunluk" kodu içerisinde } \\
\text { yer almıştır. }\end{array}$} \\
\hline & \multirow[t]{2}{*}{ 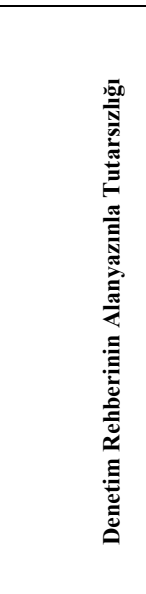 } & 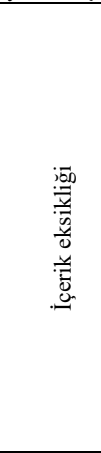 & $\begin{array}{l}\text { Rehberde: } \\
\text { Grup Sorumlusu ve Maarif Müfettişinin Görevleri, Maarif Müfettişlerinin Görevleri; } \\
\text { a) } 652 \text { sayılı Kanun Hükmünde Kararnamenin } 17 \text { nci maddesinde belirtilen görevleri yapmak, } \\
\text { b) Rehberlik, denetim, inceleme, soruşturma çalışmaları neticesinde düzenleyecekleri raporları } \\
\text { en geç yirmi gün, kapsamlı işlerde ise verilen ek süre içinde tamamlamak, } \\
\text { c) Rehberlik ve denetim çalış̧alarında mesleğin gerektirdiği özeni ve titizliği göstermek, } \\
\text { ç) Refakatlerine verilecek müfettiş yardımcılarının yetişmelerini sağlamak, } \\
\text { d) Rehberlik ve denetimlerde hizmetlerin süreç ve sonuçlarının mevzuata uygunluğunu kontrol } \\
\text { etmek, tespit ettiği özellik arz eden hususları grup sorumlusuna bildirmek, } \\
\text { e) Raporu, rehberlik ve denetim raporlama standartlarına uygun olarak düzenlemek. } \\
\text { f) Mevzuatla verilen diğer görevleri yapmak. } \\
\text { Alanyazında: } \\
\text { Bir müfettiş, sistem içindeki personelin motivasyon düzeyini arttırmak için personele rehberlik } \\
\text { etme, başarılı yönlerini takdir etme, bağlllık duygularını destekleme, başarıya yöneltme, } \\
\text { ödüllendirmeyi güdüleme aracı olarak kullanma gibi birtakım görevleri yerine getirmelidir } \\
\text { (Taymaz, 2010: 112). }\end{array}$ \\
\hline & & $\begin{array}{l}\text { Deı } \\
\text { "başlığı } \\
\text { ifadeler, } \\
\text { kısmı eks } \\
\text { "İçerik El }\end{array}$ & $\begin{array}{l}\text { rehberinde "Grup Sorumlusu ve Maarif Müfettişinin Görevleri, Maarif Müfettişlerinin Görevleri } \\
\text { a yer alan ifadeler alanyazın bağlamında incelendiğinde rehberin ilgili maddesinde belirtilen } \\
\text { görevler açısından hazırlanmış anacak alan yazında belirtilen danışmanlık ve rehberlik etme } \\
\text { ldı̆g } 1 \text { görülmüștür. Bu bağlamda ilgili ifade alanyazınla tutarsızlık kategorisi başlığı altında } \\
\text { fi" kodu içerisinde yer almıştır. }\end{array}$ \\
\hline
\end{tabular}


Uzman incelemesi ve meslektaş teyidi ile verilerin iç geçerliliği (inandırıcılık) sağlanmıştır. Meslektaş teyidi; verilerin karşılaştıılarak uyumunun ortaya çıkarılmasını hedefler. Uzman incelemesi ise araştırma sürecine eleştirel gözle bakan ve araştırmacıya geribildirimde bulunan uzman görüşünü belirtmektedir(Creswell, 2003; Yıldııım ve Şimşek, 2016). Araştırmanın geçerliğinin sağlanması için ilk olarak meslektaş teyidine gidilmiştir. Bunun için MEB Teftiş Kurulu Başkanlığı́nın farklı kurumlara yönelik olarak hazırladığı denetim rehberlerini inceleyen araştırmacılar düzenli aralıklarla her hafta belirlenen gün ve saatte internet ortamında canlı toplantı araçları üzerinden bir araya gelmiştir. Tekrar izlenebilmesi için bu toplantılar kaydedilmiştir. Toplantılarda rehberlerin hangi yönlerden incelenebileceğine ilişkin tartışmalar yapılmıştır. Sonrasında ise araştırmacılar inceledikleri rehberlere yönelik içerik analizi yaparak kodlar ve temalar oluşturmuş ve bunların benzer ve farklı yönleri üzerinde durulmuştur. Anlaşmazlığa düşülen noktalar değerlendirilmiş ve fikir birliğine varıncaya kadar toplantılar devam etmiştir. Çözüme kavuşturulan bir anlaşmazlığa örnek vermek gerekirse rehberde kapsam açısından; "MEB'e bağlı resmi ve özel ilkokul ve ortaokulların denetimini kapsar." şeklinde ifade edilmekte olup, alanyazında ise "Denetimle genel olarak yapılan kurumsal ve bireysel çalışmaların izlenmesi, kontrol edilmesi ve değerlendirilmesi veya bir sistemin daha etkili ve verimli işleyebilmesi için ilgili kişilere rehberlik ve yardımda bulunulması gibi konuları kapsamaktadır (Aypay, 2010)." denilmektedir. Bu tespitin "Alanyazın Tutarsızlık" kategorisi içerisinde "Atıfsızık" koduna örnek oluşturabileceği araştırmacı tarafından önerilmiş, ancak diğer denetim rehberlerini inceleyen araştırmacılar ve uzman görüşüne göre ifadenin ilgili koda uygun olmadığı sonucuna ulaşılmıştır. Ayrıca uzman görüşü için denetim alanında yetkin ve yayımları olan bir akademisyen ile bir maarif müfettişi bu toplantılarda yer alarak toplantı sürecinde geribildirimlerde bulunmuşlardır. Geçerlik ve güvenirliğin sağlanması için değerlendirilen rehberin görüş birliğine dayalı olarak analiz edilmesine ve ayrıntılı raporlaştııımasına dikkat edilmiştir. Son toplantının ardından çalışma alanında uzman akademisyenlere gönderilmiş ve onların görüşleri de çalışmaya dahil edilmiştir.

Birlikte hareket edilerek şekilenen rehberlerle ilgili çalışmaların bazıları yayımlanmıştır (Toprakçı ve Bakır 2020; Tonbul ve Ata 2020; Özdemir ve Altuntaş 2020; Akçay Güngör 2020; Kahraman 2020; Tonbul ve Keleş 2020; Ölmez ve Algam 2020; Toprakçı ve Özerten 2020). Bu çalışma hakem süreci ve yazım ile ilgili iş ve işlemlerin uzamasından dolayı sonra yayımlandığından onlara vurgu yapmak gereği duyulmuştur.

\section{BULGULAR VE YORUM}

Bu bölümde, araştırmadan elde edilen verilere bağı kalarak ortaya çıkan bulgulara ve bu bulgulara dayalı yorumlara yer verilmiştir. Bulgu ve yorumların ifade edilmesinde tema, kategori ve kod eksenli sunum yapılmaya çalışılmıştır.

\section{Ortaokul Rehberlik ve Denetim Rehberinin Yasal Belgeler ile ilişkisi}

Aşağıda yer alan Tablo 2'de "Denetim rehberinin yasal belgelerle ilişkisi teması" altında "Denetim rehberinin yasal belgelerle tutarlıı̆ı" ve "Denetim rehberinin yasal belgelerle tutarsızlı̆ıı" kategorileri ve kodlarının dağılımları gösterilmiştir. 
Tablo 2: Ortaokul Denetim Rehberinin Yasal Belgelerle ilişkisi temelinde kategori ve kod Dağılımı

\begin{tabular}{|c|c|c|c|}
\hline Tema & Kategoriler & Kodlar & $\mathbf{f}$ \\
\hline \multirow{11}{*}{ 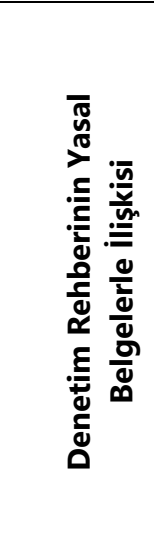 } & $\begin{array}{l}\text { 1. Denetim Rehberinin } \\
\text { Yasal Belgelerle Tutarlılığı }\end{array}$ & Yasal dayanağa uygunluk & 46 \\
\hline & \multirow{10}{*}{$\begin{array}{l}\text { 2. Denetim Rehberinin } \\
\text { Yasal Belgelerle Tutarsızlığı }\end{array}$} & Yasal Dayanağa Göre Eksik İfade Edilme & 17 \\
\hline & & Yasal Dayanağın Hatalı Ifade Edilmesi & 2 \\
\hline & & Yasal Dayanağa Göre Güncel Olmama & 5 \\
\hline & & Yasal Dayanağa Göre Fazla Iffadelendirilme & 2 \\
\hline & & $\begin{array}{l}\text { Yasal Dayanağa İnternet Ortamında } \\
\text { Ulaşamama }\end{array}$ & 3 \\
\hline & & Yasal Boşluk & 12 \\
\hline & & İlgili Yasal Dayanaklara Eksik Gönderme & 6 \\
\hline & & Yasal Dayanak Belirsizliği & 5 \\
\hline & & Toplam & 52 \\
\hline & & Toplam & 98 \\
\hline
\end{tabular}

Tablo 2 incelendiğinde "Denetim Rehberinin Yasal Belgelerle Tutarlıı̆ı" ve "Denetim Rehberinin Yasal Belgelerle Tutarsızlığı" olmak üzere iki kategorinin oluştuğu görülmektedir. Rehberde incelenen 98 maddenin içerisinde "Denetim Rehberinin Yasal Belgelerle Tutarlılı̆ı $(n=46)$ " kategorisinin "Denetim Rehberinin Yasal Belgelerle Tutarsızlı̆ı"" kategorisine (kodları temelinde) $(n=52)$ göre daha az olduğu görülmektedir. Bu kapsamda kod ve frekanslar rehberin yasal belgelerle ilişkisinin neredeyse yarı yarıya olmak üzere tutarsız olduğunu ortaya koyabilir. Tablo 2 genel olarak değerlendirildiğinde; rehberin denetime referans oluşturan yasal belgelerle tutarlı olmasının beklenen bir durum olduğu ancak rehberin yasal belgelerle tutarsızlığını ortaya koyan tespitlerin varlığının da dikkat çekici olduğu söylenebilir. Aşağıda her ikisi kapsamındaki kodlarla ilgili tespitlere yer verilmiştir.

\subsection{Denetim Rehberinin Yasal Belgelerle Tutarlılığı}

Rehberinin yasal belgelerle tutarlılığı dayandığı yasal belgelerle uyumlu bir özellik göstermesi anlamına gelmektedir. Bu uygunlukla ilgili ifadeler toplamı Tablo 2'de verilmiştir. Bu kapsamda rehberin "Yasal dayanağa uygunluk" kodu incelendiğinde rehberde geçen ifadenin atıfta bulunduğu yasal belgelere ulaşabilme durumu ve ulaşılan belgedeki ifade ile örtüşüp örtüşsmediğine bakılmıştır. Buna göre toplam ifade sayısı $46^{\prime}$ dır. Bu uyuma bir örnek şu şekilde verilebilir:

Rehberde, "Rehberlik ve denetim raporları ilgili birim ve kuruma gönderildiği tarihten itibaren bir ay içerisinde, raporda tespit edilen hususlar ve getirilen öneriler doğrultusunda, denetlenen kurumca hazırlanan gelişim planı kurumu denetleyen müfettişin bağlı olduğu Maarif Müfettişleri Başkanlığına gönderilir." ifadesi yer almaktadır. Bu ifade gönderme yaptığı yasal belge (MEB Teftiş Kurulu Yönetmeliği İzleme ve Değerlendirme kısmı 50. madde) temelinde incelendiğinde, "Kurum ve birimler, denetim ve rehberlik raporunun kendilerine ulaşmasından itibaren bir ay içerisinde raporda belirtilen tespit ve öneriler doğrultusunda, kurumsal gelişim planı hazırlayarak Başkanlığa gönderirler. Taşra teşkilatındaki birimler ve kurumlar, kurumsal gelişim planının bir örneğini ise ayrıca il/ilçe millî eğitim müdürlüklerine gönderirler." ile karşılaşılmaktadır. Görüldüğü gibi her iki ifadede de denetim raporunun bir ay içerisinde gönderileceğinden söz edilmektedir. Bu durum rehberin yasal belgeler temelinde uygunluğunu göstermekte olup rehberi kullananlar açısından yararlı sonuçlar doğurabilir.

\subsection{Denetim Rehberinin Yasal Belgelerle Tutarsızlığı}

Rehberinin yasal belgelerle tutarsızlığı dayandığı yasal belgelerle uyumlu bir özellik göstermemesi anlamına gelmektedir. Yasal dayanağa uygun olmama (tutarsızlık) kategorisi incelendiğinde toplam ifade sayısı 52'dir. Bu kapsamda rehberin yasal belgelerle tutarsızlığı kategorisi ile ilgili kodlar ayrıntılı olarak şu şekildedir: 
"Yasal Dayanağa Göre Eksik Ifade Edilme" kodu $(n=17)$, rehberde yer alan ifadelerin yasal dayanağa göre eksik ifade edilmiş olması anlamına gelmektedir. Denetim rehberinin 3.bölüm yönetim faaliyetleri içerisinde öğrenci işleri başlığı altında yer alan "ilkokul, ortaokul ve imam hatip ortaokullarında kayıt ve nakil işlemlerinin yerine getirilme durumu" kısmında MEB Okul Öncesi Eğitim ve Illköğretim Kurumları Yönetmeliği 3.bölüm yönetim faaliyetleri içerisinde öğrenci işleri başığı altında bulunan maddelerden, madde 11 ve madde 12'nin yer aldığı ancak aşağıda verilen alıntısı temelinde ilgili yönetmeliğin 15.maddesi'ne rehberde hiç değinilmediği görülmüştür:

"MEB Okul Öncesi Eğitim ve İlköğretim Kurumları Yönetmeliği Madde 15 - (1) Yatılı bölge ortaokuluna kayıtta aşağıdaki esaslara uyulur. a) Yatılı bölge ortaokulunun öğrenci alacağı yerleşim yerleri ve öğrenci sayısı, kayıtlar başlamadan en az bir ay önce il millî eğitim müdürü veya görevlendireceği il millî eğitim müdür yardımcısının başkanlığında, ilçe millî eğitim müdürleri ve yatılı bölge ortaokulu müdürlerinden oluşan bir komisyon tarafından 10 uncu maddede belirtilen planlama da dikkate alınarak tespit edilir."

Bu kapsamda yasal belgede yer alan 15. maddenin denetim rehberinde bulunmaması rehberin yasal dayanağa göre eksik ifade edildiği anlamına gelebilir. Başar (1993)'a göre denetim "Durumu saptama, değerlendirme, düzeltme ve geliştirme olarak tanımlamaktadır." Bu eksikliğin rehberin denetime hizmet etme açısından da eksiklik içinde olacağı anlamına gelebilir.

"Yasal Dayanağın Hatalı Ifade Edilmesi" kodu $(n=2)$, rehberde yer alan ifadelerin gönderme yaptığı yasal dayanağın ilgili mevzuata göre hatalı olarak ifade edilmesidir. Yönetim faaliyetleri başlığı altında 3.maddesinde yer alan "Ortaokul ve imam hatip ortaokullarında; seçmeli dersler ile ilgili iş ve işlemlerin yapılma durumu" kısmında İlköğretim Kurumlar Yönetmeliği kursların süreleri madde 7'de açıklanmakla beraber kursların açılma şeklinden madde 5 'te bahsedildiği görülmüştür.

"Madde 5: Haftalık ders programlarının hazırlanması (MEB Okul Öncesi Eğitim ve İlköğretim Kurumları Yönetmeliği Md.5)"

"Madde 7: Ders saati ve günlük çalışma saatlerinin düzenlenmesi (MEB Okul Öncesi Eğitim ve ilköğretim Kurumları Yönetmeliği Md.6/2)"

Illköğretim Kurumlar Yönetmeliği kursların süreleri 7. maddede açıklanmakla beraber kursların açılma şeklinden 5.maddede bahsetmesi yasal dayanağın hatalı ifade edildiğini ortaya koymaktadır. İlgili yönetmeliğin 7.maddesi sadece ders saati ve zaman açısından kurs sürelerinden bahsetmiştir. Söz konusu kursların nerede, nasıl, hangi hallerde ve hangi dönem içerisinde açılacağı belirtilmemiştir. Ancak ilgili yönetmeliğin 5.maddesinde kursların açılması ile ilgili bu soruların cevabı bulunmaktadır. Bu durum denetmenin yetersiz veya eksik denetim yapılmasına ya da rehberde belirtilen madde dışında denetim yapmasına neden olabilir. Ayrıca rehberi kullanacak kişilerin denetim öncesinde, denetim esnasında veya denetim sonrasında nesnel bir denetim yapmasını engelleyebilir ve denetimin geçerliğine de zarar verebilir.

"Yasal Dayanağa Göre Güncel Olmama" kodu $(n=5)$, gönderme yapılan ya da yapılması gereken yasal belgede bir değişiklik olması veya yürürlükten kaldırılması anlamına gelmektedir. Rehberde öğretim etkinlikleri, hazırlık başlığı altında yer alan; "Kaynaştırma yoluyla eğitimleri (Millı̂ Eğitim Bakanlığı Okul Öncesi Eğitim ve Ilköğretim Kurumları Yönetmeliği Md. 20/c; Özel Eğitim Hizmetleri Yönetmeliği Md. 23,24,72)" yasal dayanaklarından madde 72'nin 2018 tarih ve 30471 sayılı Özel Eğitim Hizmetleri Yönetmeliği'nin 72.maddesi incelendiğinde yönetmelikte bulunmadığı görülmüştür. Bu durum denetim rehberinde yer alan 72. maddenin yasal belgede bulunmamasından dolayı rehberin yasal dayanağa göre güncel olmadığını göstermektedir. Denetim, yönetimin sağlıklı bir biçimde işlemesi için olmazsa olmaz faaliyetlerden biridir (Doğan, 2015). Rehberdeki herhangi bir maddenin güncel olmaması rehbere göre kurumunu denetime hazırlayan bir yöneticinin yanlış yönlenmesine yol açabilir. Öte yandan olmayan bir maddeye göre denetim yapan bir müfettişin düşebileceği zor durum da göz önünde tutulmalıdır. 
"Yasal Dayanağa Göre Fazla Ifadelendirilme" kodu $(n=2)$, rehberde yer alan ifadelerin gönderme yaptığı yasal dayanağa göre fazla ifadelendirilmesi anlamına gelmektedir. Rehberde "Millı̂ Eğitim Bakanlığı Teftiş Kurulu Yönetmeliği Rehberlik ve Denetim Ilkeleri" başlığı altında yer alan ilkelerin çoğu mevzuatla örtüşürken bazı maddelerin mevzuatta yer almadığı görülmüştür;

"g) Personelin mesleki yeterliğini geliştirmek,

h) Gelecek yönelimli olmak,

i) Millî birlik ve bütünlüğümüzün temel unsurlarından biri olan Türkçenin doğru kullanılması hususunda gerekli duyarlıı̆ı göstermek.

j) Kurumlarda rehberlik ve denetim faaliyetlerini birlikte yürütmek."

Rehberde yer alan bu maddelerin ( $g, h, i, j)$ mevzuatta (MEB Teftiş Kurulu Yönetmeliği Rehberlik Ve Denetim Illkeleri Madde-47(1)) yer almaması, rehberin yasal dayanağa göre fazla ifadelendirildiği söylenebilir. Bu durum denetim esnasında, sonrasında ve denetimin raporlanmasında denetleyenin kafa karışıklığına yol açabileceği gibi nesnel bir denetim yapılmasına da engel olabilir.

"Yasal Dayanağa İnternet Ortamında Ulaşamama" kodu $(n=3)$, rehberde geçen ifadenin atıf yapılan yasal belgesine internet ortamında ulaşılamaması anlamına gelmektedir. Rehberde yönetim faaliyetleri iletişim ve yönetişim başlı̆ı altında yer alan "Okul internet sitesinin uygun ve güncel olma durumu" ifadesinde atıf yapılan "MEB insan Kaynakları Genel Müdürlügü̈ çıkışlı 28/02/2007 tarih ve 12082 sayllı yazıya" internet ortamında ulaşılamamıştır. Söz konusu durum yasal dayanağa internet ortamında ulaşamama şeklinde ifade edilmiş olup, internet ortamında ulaşılmayan belgeler denetimin ve rehberin güncelliğinin teyit edilmesini ve kontrolünü güçleştirebilir. Oysa yönetim sürecinin her bir aşamasında (Karar verme, planlama, örgütleme, iletişim, etki, koordinasyon ve değerlendirme) olduğu gibi, eğitim denetiminin aşamalarında da eğitim teknolojilerinden yararlanılması günümüzde oldukça önem taşımaktadır (Toprakçı, 2006).

"Yasal Boşluk" kodu $(n=12)$, rehberdeki içerik ile ilgili mevzuatta hiçbir yasal belgenin bulunmadığı anlamına gelmektedir. Bu duruma rehberden örnek verilecek olursa, 'Dayanak' başlığı altında "Her derece ve türdeki örgün ve yaygın eğitim kurumları ile il ve ilçe millî eğitim müdürlüklerinin rehberlik, işbaşında yetiştirme, denetim, değerlendirme, inceleme, araştırma ve soruşturma hizmetlerini Maarif Müfettişleri aracılığıyla yürütmek" şeklinde belirtilen 652 sayılı MEB Teşkilat ve Görevleri Hakkında Kanun Hükmünde Kararnamenin 17. maddesinde çalışma usul ve esasları, görevliler, görev merkezi ile ilgili herhangi bir bilgiye yer verilmediği görülmüştür.

Bir hukuk devleti olan Türkiye Cumhuriyeti'nde tüm kurum ve kuruluşlar, yasal çerçeve içerisinde tanımlanan görev ve sorumluluklarını yerine getirmektedirler. Eğitim sisteminin alt sistemlerinden olan denetim de başta Anayasa olmak üzere, yasa, tüzük, yönetmelik ve yönergelere dayalı olarak görev ve sorumluluğunu yerine getirmektedir (Arabacı, 1999). Bu bağlamda rehberde yasal belgeye dayandırılmayan ifadeler hem denetleyen açısından hem denetlenen açsından yasal bir denetimi sağlayamadığı için denetimi sorunlu hale getirebilir.

"Yasal Dayanaklara Eksik Gönderme" kodu $(n=6)$, rehberde gönderme yapılması gereken yasal bir belgeye eksik değinilmesi anlamına gelmektedir. Denetim rehberinde "Eğitim etkinlikleri okul-çevre ilişkileri sosyal ve kültürel etkinliklerin aile ve çevre ile paylaşma durumunun incelenmesi (MEB Illköğretim ve Orta Öğretim Kurumları Sosyal Etkinlikler Yönetmeliği" yer alan bu maddede ilgili yönetmeliğin hangi maddesine gönderme yaptığı bilinmemektedir. Bu kapsamda rehberdeki ifadenin ilgili yasal dayanağın hangi maddesine gönderme yaptığı veya eksik gönderme yaptığı söylenebilir. Oysa denetimde hangi konuların, ne zaman, nasıl ve kiminle inceleneceği hususlarında rehberde bilgilerin yer alması denetimin sistematiği açısından önemlidir. Değerlendirmenin asıl amacı kanıtlamak değil, geliştirmek olmalıdır. Değerlendirme, amaç-çıktı ilişkisini güçlendirmek için, girdi, işleme, çıktıdan alınacak verilerin işlenip dönüte çevrilmesidir (Aydın, 2005). l̇yi bir değerlendirme sistemi, değerlendirmeyi, öğretmeyi, 
öğrenmeyi, kendisini değerlendirmeyi kolaylaştırıcı olmalı, bireyi amaçlara uygun kanıtlar aracılığıyla sürekli dönütler sağlamalı ve kapsamlı olmalıdır.

"Yasal Dayanak Belirsizliği" kodu $(n=5)$, gönderme yapılan ya da yapılması gereken yasal belgenin tam olarak hangi belge olduğunun bilinmediğinde kullanılmıştır. Rehberde 3.bölüm yönetim faaliyetleri içerisinde yer alan, "Bu ana başlık altında araştırma ve planlama, örgütleme, öğrenci ve pansiyon işleri, insan kaynakları, denetim, izleme-değerlendirme sonuçları, iletişimyönetim ile bilişim sistemleri ele alınmıştır(MEB Özel Öğretim Kurumları Genel Müdürlüğü çıkışlı 27/10/2016 tarihli ve E.12079876 sayılı Özel Öğretim Kurumlarının Denetimi konulu yazıda yer alan hususların yerine getirilme durumu)" ifadesi incelendiğinde yasal belgeler temelinde doğrudan hangi maddeye atıf yapıldığı belirsizdir.

Etkili denetimde, amaçların tutarlılık göstermesi, plan durumuna göre tasarlanması ve esnek olması, yasalara uygun olması, işbirliği ve karşılıklı anlayışa dayanması, uygun yöntemler kullanılarak yapılması, bilgi beceri ve tutum gerektirmesi, olumlu bir güdüleme gücüne sahip olması, çözümleyici ve birleştirici olması, geçmişe ve geleceğe yönelik olması, değerlendirme ödüllendirme ve cezalandırmayı da içermesi gibi özellikler bulunmaktadır (Taymaz, 1997). Yasal belirsizlik söz konusu etkili denetim özellikleri kapsamında değerlendirilen "yasalara uygunluğa" zarar verici bir durum olarak gözükmektedir.

\section{Ortaokul Rehberlik ve Denetim Rehberinin Alanyazın ile İlişkisi}

Aşağıda yer alan Tablo 3'te "Denetim rehberinin alanyazınla ilişkisi teması" altında "Denetim rehberinin alanyazınla tutarlıı̆ı̆" ve "Denetim rehberinin alanyazınla tutarsızlı̆ı̆" kategorileri ile kodları verilmiştir. Bu kısımda denetim rehberi ya da okullar ile ilgili doğrudan bir alanyazın çalışmasının yokluğuna binaen araştırmacıların "alanyazınsal zihin çerçevesi" ve dolaylı çalışmalar temelinde hareket edildiğinden sayısallaştırmaya gidilmemiştir.

Tablo 3. "Denetim rehberinin alanyazınla ilişkisi" teması altında ortaya çıkan kategori ve kodlar

\begin{tabular}{|c|c|c|}
\hline Tema & Kategoriler & Kodlar \\
\hline \multirow{3}{*}{$\begin{array}{l}\text { Denetim Rehberinin } \\
\text { Alanyazınla İlişkisi }\end{array}$} & $\begin{array}{l}\text { 1. Denetim Rehberinin Alanyazınla } \\
\text { Tutarlılığı }\end{array}$ & Uygunluk \\
\hline & \multirow[b]{2}{*}{$\begin{array}{l}\text { 2. Denetim Rehberinin Alanyazınla } \\
\text { Tutarsızlığı }\end{array}$} & Aykırılık \\
\hline & & $\begin{array}{l}\text { Atıfsızlık } \\
\text { İçerik eksikliği } \\
\text { Kavram tutarsızlığı }\end{array}$ \\
\hline
\end{tabular}

Denetim rehberindeki ifadelerin alanyazın ile ilişkisi analizleri sonucunda Tablo 3 'da yer alan kategori ve kodlara ulaşılmıştır. Tablo incelendiğinde "Denetim Rehberinin Alanyazınla Tutarlılı̆ıı" ve "Denetim Rehberinin Alanyazınla Tutarsızlığı" olmak üzere iki kategorinin oluştuğu görülmektedir. Rehberde incelenen ifadelerin "Alanyazına Uygunluk" kodu "Denetim Rehberinin Alanyazınla Tutarlıı̆ı" kategorisi kapsamında, "Aykırılık", "Atıfızlık", "içerik Eksikliği" ve "Kavram Tutarsızlığı" "Denetim Rehberinin Alanyazınla Tutarsızlığı" kategorisi kapsamında kodların ön plana çıktığı görülmektedir. Bu kapsamda rehberin alanyazın bağlamlı olduğu ve bazı ifadeler dışında çok da farklılaşmadığı söylenebilir.

\subsection{Rehberin Alanyazın ile Tutarlılığ}

Bu bölümde denetim rehberi alanyazın bağlamlı olarak incelenmiş, alanyazınla tutarlılı̆ı kategorisi kapsamında Tablo 3' da "Alanyazına Uygunluk" kodu oluşmuştur. Rehberin alanyazınla tutarlılı̆ı, rehberde yer alan ifadelerin alanyazınla uyumlu bir özellik göstermesi anlamına gelmektedir. Bu kod ile ilgili ifadeler incelendiğinde rehberde geçen ifadelerin alanyazındaki 
ifadelerle ile genel olarak örtüştüğü anlaşılmıştır. Denetim Rehberi içerisinden "alanyazına uygunluk" kodu ile ilgili bir örnek şu şekilde verilebilir:

Rehberde "Ön çalışma kısmında belirtilen Bilgi Toplama/Ön Araştırma, Potansiyel Sorunlu Alanların Belirlenmesi (Risk Değerlendirmesi), Rehberlik ve Denetim Araçlarının Belirlenmesi, Rehberlik ve Denetim Öncesi Hazırlık Toplantısı" ifadesi yer almaktadır. Bu ifade alanyazında, "Denetimde ilk aşama denetlenecek olan belirlenmesidir. Denetlenecek olan belirlendikten sonra denetim öncesi hazırlıklar yapılır. Denetimin yapılabilmesi için gereken standartlar belirlenir. Daha sonra denetim faaliyeti gerçekleştirilir, veriler toplanır. Veriler daha önce belirlenen standartlar karşılaştııılır ve verilerin beklenen standartları ne ölçüde karşıladığı belirlenir ve son aşama olan raporlaştırma ile elde edilen veriler ve belirlenen standartlar doğrultusunda mevcut durum değerlendirmesi yapılır"(Toprakçı, 2016) ifadesi ile örtüşmektedir. Görüldüğü gibi her iki ifadede de eğitim denetimi sürecinin aşamalarından söz edilmektedir.

\subsection{Rehberin Alanyazın ile Tutarsızlığı}

Bu bölümde denetim rehberin alanyazınla ilişkisi incelenmiş, alanyazınla tutarsızlığı kategorisi kapsamında Tablo 3' de "Aykırı Durum", "Atıf Yapmama", "iç̧erik Eksikliği" ve "Kavram Tutarsızığı" kodları oluşmuştur. Rehberin alanyazınla tutarsızlığı, rehberde yer alan ifadelerin alanyazındaki ifadelerle örtüşmediği anlamına gelmektedir.

"Aykırılık" kodu, denetim rehberinin alanyazınla çelişen ve düzeltilmesi gereken bir durumun tespitini ifade eden koddur. Bu kodla ilgili bir örnek vermek gerekirse, rehberde "Rehberlik ve denetim uygulamalarında, son denetim tarihinden itibaren yürütülen iş ve işlemler esas alınır. Son denetim tarihi üç yıldan önce ise son üç yıl dikkate alınır." şeklinde belirtilmiş. Ancak alan yazında Sürekli geliştirme temeline dayalı denetimde standartlar, hedefler, yöntem ve teknikler statik değil dinamiktir(Erdem, 2006) denilmektedir. Bu kapsamda rehberde belirtilen denetim süresi ile alan yazında ifade edilen denetim süresi örtüşsmemekte ve alanyazında geliştirme odaklı bir denetimin sürekli ve dinamik olması gerektiği vurgusu yapılmaktadır

"Atıfsızık" kodu, rehberin alanyazınla ilişkisi ister tutarlı ister tutarsız olsun rehberin konusu ile ilgili yapılmış bilimsel çalışmalara gönderme yapılmaması durumunu ifade etmektedir. Rehberin hiçbir yerinde alanyazındaki herhangi bir araştırmaya, kitaba, çalışmaya atıf yoktur. Bu bulgunun elde edilmesinin sebebi olarak rehberin sadece mevzuat odaklı hazırlanarak bilimsel bilginin göz ardı edilmesi şeklinde açıklanabilir. Diğer yandan rehberin var olan haliyle alanyazınla tutarlı çıkan yanları itibariyle o kısımların gönderme yaptığı mevzuatın şekillenişi ya da oluşturulması esnasında bilimsel bilgiden hareket edilmiş olabileceğine ilişkin bir ipucu da verebilir. Zaten, eğitbilimciler eğitim pratiğinin teorilerini hazırladıklarında, bu teoriler üretildiği toplumun ve belki de uluslararası toplumun gerçekten (hukuksal anlamda) yasal belgelerine yansıdığında ancak (o ülkede ya da dünyada) eğitimin bilimliliğinden söz edilebilir (Toprakçı, 2008; Toprakçı, Dağdeviren, Oflaz ve Türe 2010). Eğitim denetimi akademisyenlerinin ürettiği bilginin işlerliği açısından uygulamadakilerin onların çalışmalarından atıf yaparak yararlanmaları hem uygulamaya nitelik kazandırmak hem de akademisyeni takdir etmek bağlamlı katkı sağlayıcı olabilir.

"içerik eksikliği" kodu, alanyazında olan fakat denetim rehberinde olmayan durumlar olması anlamına gelmektedir. Bu kapsamda ortaokul denetim rehberine yönelik ilgili alanyazın incelendiğinde "içerik eksikliği" koduna örnek vermek gerekirse "Rehberlik Denetim Esasları kısmında 1.2 Maarif Müfettişlerinin Görevleri maddesi görevleri" idari görevler açısından hazırlanmış, ancak alanyazında "Bir müfettiş, sistem içindeki personelin motivasyon düzeyini arttırmak için personele rehberlik etme, başarılı yönlerini takdir etme, bağlılk duygularını destekleme, başarıya yöneltme, ödüllendirmeyi güdüleme aracı olarak kullanma gibi birtakım görevleri yerine getirmelidir" (Taymaz, 2010: 112) denilerek alanyazında belirtilen danışmanlık ve mentörlük kısmı rehberde eksik kalmış gibi gözükmektedir. 
"Kavram Tutarsızlı̆ı" kodu, alanyazın ve rehberdeki kavramların kullanıldığı yerdeki ifadeyle tutarsız olduğu ya da birbirini kapsayan kavramlar olmadığı anlamına gelmektedir. Bu koda örnek olarak "Rehberlik Denetim Illkeleri" başlığı altında yer alan "ç) Usulsüzlük ve yolsuzlukları önleme yönelimli olmak, i) Millî birlik ve bütünlügümüzün temel unsurlarından biri olan Türkçenin doğru kullanılması hususunda gerekli duyarlıı̆ı göstermek" ilkeleri; alanyazındaki rehberlik ilkeleri olan "Denetim, iyi insan ilişkileri temeline dayalıdır. Denetim, demokratik katılımı, katılanların işbirliğini ve eşgüdümünü esas alır. Denetim, eğitim etkinliklerinin tümünü içerir. Denetim, başlayıp biten değil sürekliliği olan bir eylemdir. Denetim, nesnel bulgulara ve bilimsel esaslara dayalıdır" (Gökçe, 1994). vb. gibi ilkeler bağlamında kavram tutarsızığı içindedir. Yani denetim ilkelerinden anlaşılan şey alanyazın ve rehber için aynı değildir. Öte yandan bir ortaokul kurumunun denetimine kılavuzluk etmesi beklenen rehberde sanki Türkçe dersinin etkisi ya da Türkçe öğretmenleriyle ilgili bir takım iş ve işlemler yapılıyormuş gibi Türkçe'nin doğru kullanımını bir ilke olarak koymak isabetli gözükmemektedir. Kaldı ki Türkiye de hatırı sayııır önem ve ciddiyette bir sınavdan geçerek alınan müfettişlerin Türkçe' sinden şüphe etmek de apayrı bir sorun gibi durmaktadır.

\section{SONUÇ VE ÖNERILER}

Araştırmanın bu bölümünde elde edilen sonuçlara her bir tema, kategorileri ve kodları bazında yer verilmiştir. Sonra da bunların her birinin altına araştırmacı ve uygulamacılar için önerilere yer verilmiştir.

Denetim rehberinin alanyazın ve yasal belgeler ile ilişkisini incelemeye dönük araştırma sonucunda elde edilen bulgulardan hareketle Milli Eğitim Bakanlığı tarafından oluşturulmuş olan Ortaokul Denetim Rehberinin yasal belgelerle tutarlıı̆ının düşük, alanyazınla yüksek olduğu sonucuna ulaşılmıştır. Sonuçlar ile ilgili ayrıntı vermek gerekirse; Rehberin yasal belgelerle ilişkisi temelinde;

Yasal dayanağa göre eksik ifadelerin olduğu, yasal dayanağın hatalı ifade edildiği, rehberin yasal dayanağa göre güncel olmadığı, rehberin yer yer yasal dayanağa göre fazla ifadelendirildiği, rehberle ilgili yasal dayanağa internet ortamında ulaşılamadığı, rehberde yasal boşluklar olduğu, yasal dayanaklara eksik gönderme yapıldığı ve rehberin bazı yerleri itibariyle yasal dayanak belirsizliği içinde olduğu gibi sonuçlara ulaşılmıştır. Bu sonuçlar bağlamında uygulamacılara dönük olarak;

- Rehber yazılmadan önce gerekli hazırlıkların ve ilgili yasal belgelerin takibi ve tasnifi yapılabilir. Rehberi hazırlayanlara rehberin uygulanması kapsamında pilot uygulamalarla bilgilendirme yapılarak hem teorik hem de pratik olarak yeterlilikler kazandırılabilir.

- Rehber yazıldıktan sonra oluşturulacak e-denetim rehberi kontrol aşamasında dijital yasal dayanak havuzunda tarama yapılarak hatalı ifadelerin tespiti ve düzeltilmesi sağlanabilir.

- Sürekli bir düzeltme faaliyeti içinde ilgili yasal belgelerin takibi ve tasnifini yapacak, ilgili mevzuat değiş̧iğinde yapılan değişiklik dijital ortamda oluşturulan veri havuzuna otomatik olarak düşecek ve kendisini güncelleyecek yazılımlar geliştirilebilir.

- Teftiş Kurulu Başkanlığı́nın resmi web sayfasında yayımlanan, rehberlik ve denetim kılavuzlarının erişime açık olan ilkokul/Ortaokul Rehberlik ve Denetim Rehberinin ilgili maddelerinin yanına yasal dayanağını gösteren bağlantı linklerinin internet ortamında oluşturulması sağlanabilir. 
- Rehberi hazırlayanların rapor yazım sürecinde alan uzmanı en az iki üyenin yazım kuruluna alınarak ilgili ifadelerin yasal dayanağını oluşturulması sağlanabilir.

- Rehberin yazım sürecinin tamamlanmasından sonra yayım aşamasına geçilmeden ilgili yasal dayanaklara eksik göndermelerin tespiti ve son kontrolü sağlayacak üç kişilik kontrol ekibi oluşturulabilir.

Rehberin alanyazın ile tutarlığı incelendiğinde ise rehberin yüksek düzeyde tutarlı olduğu görülmüştür. Ortaokul denetim rehberinin alanyazınla ilişkisinin incelenmesinden elde edilen bulgulardan hareketle ortaya çıkan sonuçlar ile ilgili ayrıntı vermek gerekirse; Rehberin alanyazınla ilişkisi temelinde;

Rehber içerisindeki ifadelerin alanyazına aykırı olabildiği, rehberde alanyazına hiç atıf yapılmadığı, rehberde alanyazınsal içerik eksikliği olduğu ve rehber ile alanyazın arasında kavramsal tutarsızlığın olduğu gibi sonuçlara ulaşılmıştır. Bu sonuçlar bağlamında uygulamacılara dönük olarak;

- Rehber hazırlayıcıların alanyazından (eğitim denetimi) beslenen nitelikte olabilmeleri adına intisas (yüksek lisans, doktora) yapmış olmaları ya da sonra da yapmaları sağlanabilir.

- Rehber oluşturma sürecinin başında, esnasında ve sonunda olmak üzere rehber sürekli olarak alanyazınla karşılaştıılarak güncel tutulmaya çalışılabilir.

- Kısa vadeli olarak denetim rehberi yazım kurullarının yazım sürecinde alanyazından uzman iki misafir üye ile birlikte rehberi oluşturması ve kontrolü sağlanabilir.

- Rehberin alanyazınsal doygunluğunu sağlamak amacıyla alana katkı sağlayan araştırmacıların geniş ölçekte görüşlerinin alınması sağlanabilir.

- Rehber oluşturma sürecinin başında, esnasında ve sonunda olmak üzere rehber sürekli olarak yazım kurulu uzmanları ile alan uzmanlarının bir araya gelebileceği yüz yüze ve uzaktan etkileşimli görüşmeler yapılarak sorunlar giderilebilir.

Araştırmanın rehberin gerek yasal belge gerek alanyazınsal ilişkisine dönük elde edilen sonuçlarıyla ilgili olarak araştırmacıların neler yapabileceğine gelince; bu çalışmanın sınırlıklarının ötesine geçebilen araştırmalar yapabilecekleri gibi özellikle rehber ile uygulama arasındaki ilişkiyi ortaya koyan çalışmalar yapmaları Türkiye'nin eğitim denetimini daha nitelikli hale getirmeye katkı sağlayabilir.

\section{KAYNAKLAR}

Akçay Güngör, A. (2020). Özel Öğrenci Etüt Eğitim Merkezi Rehberlik ve Denetim Rehberinin Yasal Belgeler ve Alanyazın Temelinde İncelenmesi. e-Uluslararası Eğitim Araştırmaları Dergisi, 11 (3) , 90-109. Retrieved from http://www.e-ijer.com/tr/pub/issue/58698/820632

Akyüz, Y. (2007). Türk Eğitim Tarihi. Ankara: Pegem Akademi Yayıncılık.

Altunya, N. (1973). Öğretmen Gözüyle İlköğretimde Teftiş. Eğitim Sen Dergisi. İnternet'ten 9 Nisan 2020'da elde edilmiştir: http://e-kutuphane.egitimsen.org.tr/df/886.pdf

Arabacı, İ.B. (1999). "MEB Teftiş Politikası". Kuram ve Uygulamada Eğitim Yönetimi, 5 (20), 545-575.

Aydın, İ. (2005). Öğretimde Denetim Durum Saptama Değerlendirme ve Geliştirme. Ankara: Pegem Akademi Yayıncılık.

Aydın, M. (2000). Çağdaş Eğitim Denetimi. Hatipoğlu Yayıncılık.

Aypay A. (2010). "Denetici Profiline İlişkin Sorunlar ". Türk Eğitim Bilimleri Dergisi, 8(3), 593-622.

Başar, H. (1993). Eğitim Denetçisi, Rolleri, Yeterlilikleri, Seçilmesi, Ankara: Pegem Yayıncılık.

Başar, H. (1998). Eğitim Denetçisi. Ankara: Pegem Akademi Yayıncılık.

Beytekin, O. F. (2017). Ortaokul Müdürlerinin Öğretimsel Denetime Ilişkin Görüşlerinin İncelenmesi. Turkish Studies International Periodical for the Languages, Literature and History of Turkish or Turkic. Volume $12 / 3,115-128$ 
Bozkurt, N. (2005). Türkiye ile Bazı Avrupa Birliği Ülkelerindeki Okul Yöneticilerinin Yetiştirilme ve Atanma Süreçlerinin Karşılaştııılması. Malatya: İnönü Üniversitesi. (Yayınlanmış Yüksek Lisans Tezi).

Creswell, J. W. (2003). Research design: Qualitative, Quantitative, And Mixed Methods Approaches. California: Sage Publications Inc.

Demirtaş, H. ve Akarsu, M. (2016). Öğretmen Teftişini Müfettiş Yerine Okul Müdürünün Yapmasına Iliş̧kin Öğretmen Görüşleri. Inönü Üniversitesi Eğitim Fakültesi Dergisi, 17(2), 69-93. DOI: 10.17679/iuefd.17251239.

Demirtaş, H. ve H. Güneş. (2002). Eğitim Yönetimi ve Denetimi Sözlüğü. Ankara: Anı Yayıncılık.

Doğan, K . (2015). Yönetimin Bir Fonksiyonu Olarak Denetim ve Kamu Yönetimindeki Yeri. Ombudsman Akademik, (3), 107-141. DOI: 10.32002/ombudsmanakademik.439673

Erdem, Ali Rıza (2006) Öğretimin Denetiminde Yeni Bakış Açısı: "Sürekli Geliştirme" Temeline Dayalı Öğretimin Denetimi. Selcuk University Social Sciences Institute Journal . 2006, Vol. 16, p275-294. 20p.

Glesne, C. \& Peshkin, A. (1992). Becoming Qualitative Researchers An Introduction. London: Longman Group Ltd.

Glickman, C. D., Gordon, S. P., \& Ross-Gordon, J. M. (2004). Supervision and instructional leadership: a development approach (6th ed.). Boston: Allyn and Bacon.

Gökçe, F. (1994). "Eğitimde Denetimin Amaç ve İlkeleri". Hacettepe Üniversitesi Eğitim Fakültesi Dergisi, (10):73-78

Kahraman, H. (2020). Öğretmenevleri, Öğretmenevi ve Akşam Sanat Okulları Rehberlik ve Denetim Rehberinin Yasal Metinler ve Alanyazın Temelinde İncelenmesi. e-Uluslararası Eğitim Araştırmaları Dergisi, 11 (3) , 123-138. Retrieved from http://www.e-ijer.com/tr/pub/issue/58698/836759

Karasar, N. (2007). Bilimsel Araştırma Yöntemi Kavramlar İlkeler Teknikler. Ankara: Nobel Yayıncılık.

Kuzgun, Y. (1997) Rehberlik ve Psikolojik Danışma, Ankara: ÖSYM Yayını.

MEB. (1924). Tevhid-i Tedrisat Kanunu. 6.3.1924 tarih ve 63 sayılı Resmi Gazete.

MEB. (1973). 1739 sayılı Milli Eğitim Temel Kanunu. 24.6.1973 tarih ve 14574 sayılı Resmi Gazete.

MEB. (1992). Milli Eğitim Bakanlığı Teşkilat ve Görevleri Hakkında Kanun. 12.5.1992 tarih ve 179 sayılı Resmi Gazete.

MEB. (2002). Okul-Veli İşbirliği konulu Genelge (2002/27 sayılı, mülga), http://mevzuat.meb.gov.tr/dosyalar/1381.pdf, Erişim tarihi 12.05.2020

MEB. (2010).5984 Sayılı MEB Teşkilat ve Görevleri Hakkında Kanun ile Devlet Memurları Kanununda Değişiklik Yapılmasına Dair Kanun.13 Haziran 2010 tarih ve 27610 sayılı Resmi Gazete.

MEB. (2011).652 Sayılı MEB Teşkilat ve Görevleri Hakkında Kanun Hükmünde Kararname.14.09.2011 tarih ve 28054 sayılı Resmi Gazete.

MEB. (2012). Özel Öğretim Kurumları Yönetmeliği, https://www.mevzuat.gov.tr/mevzuat?MevzuatNo=15970\&MevzuatTur=7\&MevzuatTertip=5 ,Erişim tarihi 11.05 .2020

MEB. (2014).6528 Milli Eğitim Temel Kanunu ile Bazı Kanun ve Kanun Hükmünde Kararnamelerde Değişiklik Yapılmasına Dair Kanun.14.03.2014 tarih ve 28941 sayılı Resmi Gazete.

MEB. (2014). Rehberlik ve Denetim Başkanlığı ile Maarif Müfettişleri Başkanlıkları Yönetmeliği. 24 Mayıs 2014 tarih ve 29009 sayılı Resmi Gazete.

MEB. (2015). Millî Eğitim Bakanlığının Kısa Tarihçesi, http://www.meb.gov.tr/milli-egitim-bakanliginin-kisatarihcesi/duyuru/8852, Erişim tarihi 11.05.2020

MEB. (2017-a). Teftiş Kurulu Yönetmeliği, https://www.mevzuat.gov.tr/mevzuat?MevzuatNo=23861\&MevzuatTur=7\&MevzuatTertip=5 ,Erişim tarihi 15.05 .2020

MEB. (2017-b). Millî Eğitim Bakanlığı Eğitim Kurumları Sosyal Etkinlikler Yönetmeliği, https://www.mevzuat.gov.tr/mevzuat?MevzuatNo=23639\&MevzuatTur=7\&MevzuatTertip=5 ,Erişim tarihi 15.05 .2020

MEB. (2017-c). Teftiş Kurulu Başkanlığı Görev, Yetki, Sorumluluk ve Çalışma Esaslarına Dair Yönerge, https://tkb.meb.gov.tr/meb_iys_dosyalar/2018_07/04160747_yonerge.pdf , Erişim tarihi 14.05.2020

MEB. (2018). Özel Eğitim Hizmetleri Yönetmeliği, https://www.mevzuat.gov.tr/mevzuat?MevzuatNo=24736\&MevzuatTur=7\&MevzuatTertip=5 , Erişim tarihi 15.05 .2020

MEB. (2019). Bakanlık Maarif Müfettişleri Görev Standartları, https://tkb.meb.gov.tr/meb_iys_dosyalar/2019_06/19145017_BakanIYk_Maarif_MuYfettisYleri_GoYre v_StandartlarY.pdf , Erişim tarihi 04.06.2020

Neuman, W. L. (2012). Toplumsal Araştırma Yöntemleri: Nicel ve Nitel Yaklaşımlar III. Cilt (5. Basım). İstanbul: Yayın Odası. 
Nolan, J. F., \& Hoover, L. A. (2008). Teacher Supervision \& Evaluation: Theory into Practice (2nd ed.). Hoboken, N.J.: Wiley.

Ölmez Ceylan, Ö, Algam, E. (2020). İl/ilçe Milli Eğitim Müdürlükleri Denetim Rehberinin Yasal Belgeler ve Alanyazın Temelinde İncelenmesi. e-Uluslararası Eğitim Araştırmaları Dergisi, 11 (3) , 179-198 . Retrieved from http://www.e-ijer.com/tr/pub/issue/58698/831894

Öz, F. (2003). Türkiye Cumhuriyeti Milli Eğitim Sisteminde Teftiş. Eskişehir: Osmangazi Üniversitesi Yayınları.

Özdemir, N, Altuntaş, F. (2020). Denetimde Standartlaşma Çabaları: Motorlu Taşıt Sürücüleri Kursu Denetim Rehberi Örneği. e-Uluslararası Eğitim Araştırmaları Dergisi, 11 (3) , 79-89. Retrieved from http://www.e-ijer.com/tr/pub/issue/58698/807767

Özdemir, T. (2001). Çağdaş ve Demokratik Eğitimde Teftiş. Bolu: Abant İzzet Baysal Üniversitesi. (Yayınlanmış Doktora Tezi).

Öztürk, S. (1996). Türk Eğitim Sisteminde Denetim ve Denetmen Yetiştirme Sürecinin Analizi. Malatya: İnönü Üniversitesi. (Bilim Uzmanlığı Tezi).

Pehlivan, İ. (2000). Okul-Çevre İlişkileri, (Yönetici Adaylarının Eğitimi Ders Notları), Ankara Üniversitesi Yayınları, Ankara.

Resmi Gazete (2007). 5580 sayılı Özel Öğretim Kurumları Kanunu, https://www.mevzuat.gov.tr/MevzuatMetin/1.5.5580.pdf , Erişim tarihi 12.05.2020

Resmi Gazete (2014). Millî Eğitim Bakanlığı Okul Öncesi Eğitim ve Illköğretim Kurumları Yönetmeliği, https://www.resmigazete.gov.tr/eskiler/2014/07/20140726-4.htm, Erişim tarihi 25.05.2020

Resmi Gazete (2018). Millî Eğitim Bakanlığı Okul Öncesi Eğitim ve İlköğretim Kurumları Yönetmeliğinde Değişiklik Yapılmasına Dair Yönetmelik, https://www.resmigazete.gov.tr/eskiler/2018/01/20180131-3.htm, Erişim tarihi 25.05.2020

Sabancı, A. ve Şahin, A. (2007). Denetmenlerin, Öğretmenlik Yeterlik Alanları Açısından Devlet İlköğretim Okulu Sınıf Öğretmenlerine Rehberlik Görevlerini Gerçekleştirme Düzeyleri. Eğitim ve Bilim, 32(145),85-95.

Sergiovanni, T. J. ve Starratt, R. J. (1988). Supervision Human Perspective. The United States of America: McGraw- Hill, Inc.

Shenton, A. (2004). Strategies For Ensuring Trustworthiness In Qualitative Research Projects. Education for Information, 22, 63-75.

Sullivan, S. ve Glanz, J. (2000). Alternative Approaches to Supervision: Cases From the Field. The Journal of Curriculum and Supervision, 15 (3), 212-235.

Şişman, M. (2007). Eğitim Bilimine Giriş. Ankara: Pegem Akademi Yayıncılık, 3. Baskı.

Taymaz, H. (1997). Eğitim Sisteminde Teftiş, Kavramlar, İlkeler, Yöntemler. Ankara: TAKAV Matbaası.

Taymaz, H. (2002). Eğitim Sisteminde Teftiş. Ankara: Pegem Akademi Yayıncılık. 5. Baskı.

Taymaz, H. (2010). Eğitim Sisteminde Teftiş: Illkeler, Kavramlar, Yöntemler. Ankara: Pegem A Yayınları.

Tonbul, Y, Ata Çiğdem, F. (2020). Bilsem Denetim Rehberinin Yasal Belgeler ve Alanyazın Temelinde İncelenmesi. e-Uluslararası Eğitim Araştırmaları Dergisi, 11 (3) , 36-62. Retrieved from http://www.eijer.com/tr/pub/issue/58698/804118

Tonbul, Y, Ödemiş Keleş, N. (2020). Mesleki Eğitim Merkezleri Rehberlik ve Denetim Rehberi' nin Yasal Belgeler ve Alanyazın Temelinde Tutarlılığının İncelenmesi. e-Uluslararası Eğitim Araştırmaları Dergisi, 11 (3) , 139-153. Retrieved from http://www.e-ijer.com/tr/pub/issue/58698/803653

Toprakçı, E. (2004). Sını Örgütünün Yönetimi. Ankara: Ütopya Yayınevi.

Toprakçı, E. (2006). "Primary Schools and Compulsory Education in Turkey" International Journal of Educational Reform (IJER), Winter 2006. Internet'ten 12 Haziran 2009'da elde edilmiştir: http://www.rowmaneducation.com/Journals/IJER/Winter06.shtml

Toprakçı, E. (2008). Sınıfa Dayalı Yönetim. Ankara: Pegem Akademi Yayıncılık.

Toprakçı, E., Çakırer, I.., Bilbay, A., Bağcivan, E., Bayraktutan, İ. (2010). Kuram ve Uygulamada Eğitim, Denetmenleri Meslek Etiği. Educational Policy Analysis and Strategic Research, Cilt:5 Sayı:1.

Toprakçı, E. „Dağdeviren, İ., Oflaz, G., ve Türe, E. (2010) Eğitim Fakültesi Öğretim Elemanlarının Bilim Anlayışları Temelinde Eğitimin Bilimliliği" Bilim ve Ütopya Dergis, Sayı: 190, Yıl: 10, Nisan 2010, ss. 45-56 https://www.erdaltoprakci.com.tr/wp-content/uploads/2020/05/bilimanlay\%C4\%B1\%C5\%9Flar\%C4\%B1-temelinde-e\%C4\%9Fitimin-bilimlili\%C4\%9Fi.pdf

Toprakçı, E. \& Güngör, A. A. (2014). Türkiye'deki Siyasal Partilerin Eğitim Politikaları. Educational Policy Analysis and Strategic Research, 9(1)

Toprakçı, E. ve Ayşegül Kadı (2014) "Türkiye'deki Bakanlıkların Eğitim Yönetimi ve Denetimi Alanındaki Faaliyetlerinin Yasal Belgeler Eşliğinde Analizi" Celal Bayar Üniversitesi Sosyal Bilimler Dergisi, Yıl : 2014 Cilt :12 Sayı :4 ss. 1-18. 
Toprakçı, E , Akçay, A . (2016). Türkiye'de Kamu Yararına Çalışan Derneklerin Eğitim Faaliyetlerinin Yönetimi ve Denetimi (Yasal Belgeleri Temelinde Nitel Bir Analiz) . Cumhuriyet Uluslararası Eğitim Dergisi, 5 (1) , 29-52. DOI: 10.30703/cije.321382

Toprakçı, E., Beytekin, O.F. ve Doğan, M. (2018).Yargıtay'ın Özel Öğretim Kurumlarına İlişkin Verdiği Kararların Incelenmesi - Investigation of the Decisions of the Supreme Court Related to Private Education Institutions, Turkish Studies Educational Sciences, Volume 13/19, Summer 2018, p. 17811795 DOI Number: http://dx.doi.org/10.7827/TurkishStudies.14133 ISSN: 1308-2140.

Toprakçı, E. ve Bakır, D. (2019). 2012-2017 yılları arası Milli Eğitim Bakanlığı Sayıştay denetim raporlarının incelenmesi. Y. Kondakçı, S. Emil ve K. Beycioğlu (Ed.) 14. Uluslararası Eğitim Yönetimi Kongresi içinde (s. 829-834). Ankara: Orta Doğu Teknik Üniversitesi.

Toprakçı, E, Bakır, D. (2020). Yabancı, Azınlık ve Milletlerarası Okullar Denetim Rehberinin Yasal Belgeler ve Alanyazın Temelinde İncelenmesi. e-Uluslararası Eğitim Araştırmaları Dergisi, 11 (3) , 16-35. Retrieved from http://www.e-ijer.com/tr/pub/issue/58698/800326

Toprakçı, E, Özerten, K. (2020). Özel Öğrenci Yurtları Rehberlik ve Denetim Rehberinin Yasal Belgeler ve Alanyazın Temelinde İncelenmesi. e-Uluslararası Eğitim Araştırmaları Dergisi, 11 (3) , 199-216. Retrieved from http://www.e-ijer.com/tr/pub/issue/58698/817509

Yıldırım, A. ve Şimşek H. (2005). Sosyal Bilimlerde Nitel Araştırma Yöntemleri. Ankara: Seçkin Yayıncılık. 5. Baskı.

Yıldırım, A. ve Şimşek H. (2011). Sosyal Bilimlerde Nitel Araştırma Yöntemleri. Ankara: Seçkin Yayıncılık. Yıldırım, A. \& Şimşek, H. (2016). Sosyal Bilimlerde Nitel Araştırma Yöntemleri. Ankara: Seçkin. 


\section{The Examination of the Supervisory Guideline of Middle School Based on Legal Documents and Literature}

\author{
Prof. Dr. Erdal Toprakçı \\ Ege University-Turkey \\ erdal.toprakci@ege.edu.tr
}

\author{
Ahmet Bulut (M.A.Stud.) \\ Ministry of National Education-Turkey \\ ahmetbulut.1907.ab@gmail.com
}

\begin{abstract}
The purpose of this research is to offer recommendations to researchers and implementers by analyzing the Middle School Supervisory Guideline to produce more qualified and more practical guidelines based on literature and legal documents. In this research, document analysis method was used based on qualitative research. Content analysis was used to analyze the data. The data sources of the research were published on the official web page of the National Education Ministry Inspection Board "Middle School Supervisiory Guideline", the legal documents related to the guidance and supervision of the Ministry of National Education (legislative decree, law, regulation, directive, and circular) and the literature related to educational supervision. According to the results of the research, the Middle School Supervisiory Guideline was inconsistent with the legal documents and found that it was most "under-expressed according to the legal basis". When the Middle School Supervisiory Guideline was examined with context, it was concluded that the disunity consistent with the literature was " the literature of reference" "." To avoid problems that may be caused by the guide in the supervision of middle schools, it may be suggested that the guideline should be further associated with legal documents and literature.
\end{abstract}

Keywords: Education, Educational supervision, Middle school, Supervision guideline.

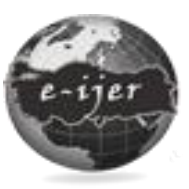

E-International Journal of Educational Research, Vol: 12, No: 1, 2021, pp. 16-35

DOI: 10.19160/ijer.830418

\section{Suggested Citation:}

Toprakçı, E. \&. Bulut, A. (2021) The Examination of the Supervisory Guideline of Middle School Based on Legal Documents and Literature, E-International Journal of Educational Research, Vol: 12, No: 1, 2021, pp. 16-35, DOI: 10.19160/ijer.830418 


\section{EXTENDED ABSTRACT}

Problem: In the social structure, there are institutions and organizations, such as religion, politics, law, economy, entertainment, welfare, transportation-communication, education, and security (Toprakçl, 2008). The most important of these institutions and organizations is education. When viewed from the aspect of the process of education's evolution, it is seen that education is one of the most important factors that play a huge role in the development and modernization of societies. For this reason and the importance, it carries, it has been one of the duties that must be fulfilled by the government officials. Because of the educational institutions' achievement of organizational qualifications, these institutions' management and their supervision became an especially important process. In modern administrations, it cannot be mentioned of a system that does not set targets, plan any planning to do targets, and evaluate applications' results. It is a necessity to control what is produced and performed, to correct deficiencies and errors to achieve the goals. Supervision, in today, is seen as a method to improve teaching and school's success by accomplishing cooperation between educators (Glickman vd., 2004) or it is seen as an instructional dialogue process in which teachers participate in order to improve student's success and develop the teaching (Sullivan and Glanz, 2000). Supervision of schools/institutions, on the other hand, is monitoring the process of the human and material resources to be supplied, be utilized, be controlled, and be assessed according to the certain criteria, in order to implementation of the purposes of the educational institutions (Demirtaş and Güneş, 2002). In another expression, it is the all of the supervision activities that determine their efficiencies of the schools and institutions' education and training activities and administration studies, in terms of still effective official texts, trains the personnel on the work, determines the level of the reach for educational targets and purposes. (MoNE, 2019). In this context, the Ministry of National Education (MoNE) is the legal institution responsible for educational supervision in Turkey. According to the MoNE Inspection Board Regulation which came into effect with the publishing 20.08.2017 dated, 30160 numbered T.C. Legal gazette, supervision of the institutions in the schools is carried out by the Maarif Inspectors (MoNE, 2017). In this framework, Guidance and Control Guides (Rehberlik ve Denetim Rehberleri in Turkish) is prepared by the MoNE Inspection Board Department in order to be the mentor to the Maarif Inspectors when they carry out their tasks and guide the Maarif Inspectors. One of these guides is the "Middle School Guidance and Supervision Guideline (Ortaokul Rehberlik ve Denetim Rehberi in Turkish)." To obtain the effectiveness of the Guideline to guide the supervision activities in the best way, it needs to have the smallest amount of errors. In the context, examination, which is especially based on the educational supervision literature and official document to subject to the scientific analysis, would be beneficial. One can say that middle school supervision activities included in the literature but any studies about the Middle School Supervision Guideline which is prepared by the MoNE are not encountered. Within this framework, in order to create more qualified and depth work, the purpose of our research is the determining its consistent and inconsistent sides of the Guide, examining the guide's practice deficiencies, offering suggestions on the basis of the literature and official documents by subjecting the Middle School Supervision Guideline to analysis. For this main purpose, it is looked to examine the Supervision Guideline's consistencies and inconsistencies with the literature and official documents.

Method: In this research, the method of examination documents, which is one of the methods of qualitative research is used. Supervision inspections are, for ensuring the unity of practice, are the publicly reachable documents used by the Inspection Board, which are right for document analysis. Because of this, in this research, stages of document analysis are followed. Inspection Board published 16 (sixteen) Supervision Guidelines for the various institutions in 2016. This research document is the "Middle School Guidance and Supervision Guideline (Ortaokul Rehberlik ve Denetim Rehberi in Turkish). Data are analyzed with content analysis. During the analysis of the data, prior codes, categories, sub-themes, and themes are constructed in the referenced guide and related legal documents after the prior reviews. For strengthening to understanding the 
transformation of data to the findings, digitization of data is also used. Lastly, research is supported and commented on the citations which are suitable for the themes. Some of the expressions in the Guideline are examined under the same theme separately because of the referenced legal document's extent, detailed content, and relevancy to the more than one theme. For this reason, the related factor is used over again in every theme when it is digitized. Data's internal validity (reliability) is ensured with expert examination and colleague approval. With the purpose, researchers that examining supervision instructions of different institutions met on a certain day and time every week via live meeting on the internet. Researchers analyzed the content of the guidelines which they examined, constructed codes and themes, and focuses on the similar and different sides of it. Also, one academician and one inspector joined to these meetings and gave feedback during the meetings. Lastly, this research's raw data is preserved for the external reliability (verifiability).

Findings: When the Supervision Guideline is analyzed, its consistent and inconsistent sides became revealed, according to categories of the legal documents and literature. The legal documents which are mentioned in the Guideline are now not current or abolished from effectiveness. Also, it is determined that there are no references to the related legal documents and in some statements, there is lacking references. It is decided that some legal documents that are mentioned as the foundation of the Guideline are not available on the internet. Furthermore, according to the foundations of the legal documents, some statements are figured out as lacking, false, or more detailed. Since legal documents were removed from effectiveness and the new one did not prepare, some statements did not have a legal basis. Also, according to the literature, some statements' content lackings are found and these statements' absence of referring to the scientific studies is determined. It has been revealed that some terms usage was inconsistent with the literature or were contrary to the literature.

Suggestions: For the aim of the elimination of this supervision guideline's inconsistency by the MoNE, before the guide is written, necessary preparations and follow-up and grading of the related legal documents can be applied. Also, before the guideline is written, both theoretical and practical qualifications can be given to the people who prepare the guideline by pilot projects in the context of the preparations of the guideline. Software that allows changes in the related legislation to fall into the data repository in digital media and can automatically update itself can be developed. After the guideline's writing process completed, a control team consists of three people who can be formed to the determination of lacking possible references to the legal documents and make the final check. Regarding the contrasts between the statements in the supervision guideline and the literature, the E-data repository which would be contextualized with the literature can be created to compare the statements in the guideline to the literature. Lastly, Supervision Guideline editorial boards can make face to face meetings and distance meetings with the experts in the literature in the writing process, and preparation of the guide can be provided. 